\title{
The Effect of Decitabine Combined with Arsenic Trioxide on DAPK Gene and HL-60 Cell Proliferation and Apoptosis
}

\author{
Jinhai Ren, Jingjing Yao, Xiaonan Guo, Xiaoling Guo, Shengxin Cai \\ Department of Hematology, Secondary Hospital of Hebei Medical University, Hebei Hematology Institute, \\ Shijiazhuang, China \\ Email: renjinhai1966@126.com
}

Received 27 October 2015; accepted 12 December 2015; published 15 December 2015

Copyright (C) 2015 by authors and Scientific Research Publishing Inc.

This work is licensed under the Creative Commons Attribution International License (CC BY). http://creativecommons.org/licenses/by/4.0/

(c) (i) Open Access

\section{Abstract}

Purpose: Our study was to detect the effect of Decitabine (DAC) combined with arsenic trioxide $\left(\mathrm{AS}_{2} \mathrm{O}_{3}\right)$ on DAPK gene and HL-60 cell proliferation and apoptosis. Methods: DAC and $\mathrm{AS}_{2} \mathrm{O}_{3}$ monotherapy, combination treatment and DAC pretreatment were used in this study after incubating with HL-60 cell for $24 \mathrm{~h}, 48 \mathrm{~h}, 72 \mathrm{~h}$. CCK8 was used to detect the cell proliferation of HL-60 cell. Flow cytometry was used to detect the cell apoptosis. Then, we used RT-PCR to obtain the gene expression level of DAPK. Results: HL-60 cells were treated with different concentrations of DAC $(20 \mu \mathrm{mol} / \mathrm{L}, 40 \mu \mathrm{mol} / \mathrm{L}, 80 \mu \mathrm{mol} / \mathrm{L}), \mathrm{AS}_{2} \mathrm{O}_{3}(1 \mu \mathrm{mol} / \mathrm{L}, 2.5 \mu \mathrm{mol} / \mathrm{L}, 5 \mu \mathrm{mol} / \mathrm{L})$ monotherapy for $24 \mathrm{~h}$, $48 \mathrm{~h}, 72 \mathrm{~h}$; along with the extension of the drug concentration and time, proliferation inhibition rate had gradually increased. Monotherapy of DAC, $\mathrm{AS}_{2} \mathrm{O}_{3}$ could inhibit the proliferation and induce apoptosis of HL-60 cells, and was time- and dose-dependent. DAC ( $80 \mu \mathrm{mol} / \mathrm{L})$ was firstly used for pretreatment, and then, different concentrations of $\mathrm{AS}_{2} \mathrm{O}_{3}(1 \mu \mathrm{mol} / \mathrm{L}, 2.5 \mu \mathrm{mol} / \mathrm{L}, 5 \mu \mathrm{mol} / \mathrm{L})$ were used for $24 \mathrm{~h}, 48 \mathrm{~h}, 72 \mathrm{~h}$. It was found that cell proliferation inhibition rate and apoptosis rate had increased significantly. When the two drugs were used together, the increasing proliferation inhibition rate, apoptosis rate and DAPK had become more obvious. Conclusion: DAC and $\mathrm{AS}_{2} \mathrm{O}_{3}$ had a synergetic effect for the HL-60 cell proliferation inhibition, apoptosis and expression of DAPK.

\section{Keywords}

Decitabine, Arsenic Trioxide, HL-60, Proliferation, Apoptosis, DAPK

\section{Introduction}

Acute Leukemia (AL) is one of the common malignant tumors in China, originating from malignant clonal he-

How to cite this paper: Ren, J.H., Yao, J.J., Guo, X.N., Guo, X.L. and Cai, S.X. (2015) The Effect of Decitabine Combined with Arsenic Trioxide on DAPK Gene and HL-60 Cell Proliferation and Apoptosis. Journal of Cancer Therapy, 6, 1229-1237. 
matopoietic stem cell. Acute Myelocytic Leukemia (AML) accounts for about 70\% of the total number of leukemia. The disease progresses rapidly with a high mortality and the course of disease is only a few months. At present, the pathogenesis of leukemia is still not clear; therefore, investigating the pathogenesis and the application of new treatments has been the main exploration direction. DNA methylation is an epigenetic modification. The hypermethylation of the gene promoter in human leukemia is related to the cell cycle regulation, apoptosis, adhesion between cells and DNA repair [1] [2], and the normal expression of gene silencing caused cancer. Different from gene mutations, DNA methylation is a biological process which can be reversible; therefore, the application of DNA methyltransferase (DNMT) inhibitors could make certain tumor gene demethylation, thus restoring its normal function. Aberrant methylation of promoter in carcinogenesis process is an early and frequent event, and it can be used as sensitive biomarkers of tumorigenesis.

Decitabine (DAC) as a specific DNA methylation inhibitor could pass directly into the DNA by phosphorylation, inhibit DNA methyltransferase, reverse the process of DNA methylation and further make the tumor suppressor gene re-expression because of methylation inactivation, causing hypomethylation of DNA and cellular differentiation or apoptosis to exert anti-tumor effects [3]. DAC has a good effect in a variety of malignant blood diseases, and there are few side effects [4]-[6], especially in myelodysplastic syndrome transformed into acute leukemia [7]. DAC treatment of lymphoma and many solid tumors (such as melanoma and colon cancer) is also in the process of clinical trials [8]-[10]. Several studies have confirmed that, DAC could induce apoptosis and promote the role of differentiation in a variety of leukemia cell lines and further enhance the sensitivity of some traditional chemotherapy drugs in the cell lines, which is very promising for anticancer drugs [10] [11].

Chinese first used arsenic agent in the treatment of leukemia. At present, the research on the treatment of $\mathrm{AS}_{2} \mathrm{O}_{3}$ has been deep, and the clinical curative effect is obvious, especially for the treatment of Acute Promyelocytic Leukemia (APL) induced apoptosis, and promoting differentiation of the targeted therapy effect is particularly prominent. In addition to the obvious effect of $\mathrm{AS}_{2} \mathrm{O}_{3}$ on APL, for other types of leukemia cells (such as HL-60 and K562) and some solid tumor cells, they have obvious effect on inhibiting proliferation and inducing apoptosis [12] [13]. $\mathrm{AS}_{2} \mathrm{O}_{3}$ has anti-leukemia cells, inducing apoptosis and promoting cell differentiation of triple role, but also it has demethylation [14]. So, it can be used as a kind of demethylation drugs in clinical application.

Death associated protein kinase (DAPK) is a calmodulin-regulated serine/threonine protein kinase and it is a positive regulator of apoptotic factor [15]. DAPK can participate in IFN- $\gamma$, TNF- $\alpha$, P53, and other cell-mediated apoptotic signaling pathway [16]-[18]. DAPK is characterized by a conserved $\mathrm{Ca}^{2+} /$ Calmodulin (CaM) regulatory domain, a serine/threonine kinase domain, and several conserved noncatalytic domains. DAPK also participates in autophagic death and caspase-independent necrotic death under certain cellular settings [19]. This broad involvement in cell death is attributed to the ability of DAPK to activate multiple death-promoting molecules and pathways [20]. Furthermore, the actin cytoskeleton-localized DAPK controls cell morphological changes associated with cell death. Research confirms that DAPK was widely expressed in normal tissues; however, the expression was relatively low in the head and neck, respiratory tract, urogenital tract and blood [18], which was mainly because of the hypermethylation of DAPK gene promoter CpG island in tumor cells [21]-[23].

In this study, DAC and $\mathrm{AS}_{2} \mathrm{O}_{3}$ of different concentrations monotherapy and two-drug combination treatment were used in HL-60 cells. CCK8 method and flow cytometry were used to detect the cell proliferation, and apoptosis. Reverse transcription polymerase chain reaction (RT-PCR) was performed to obtain the DAPK mRNA expression level in HL-60 cells and our study aimed to use it effectively in clinical application, which may provide a theoretical basis for the treatment of AML.

\section{Materials and Methods}

\subsection{Cell Lines Culture and Grouping Type}

Human acute myeloid leukemia cell line (HL-60) was purchased by the Chinese Academy of Sciences Shanghai Institutes for Biological Sciences Cell Resource Center. 20\% FBS (Fetal bovine serum, FBS), penicillin (100 $\mathrm{U} / \mathrm{ml})$ and streptomycin $(100 \mu \mathrm{g} / \mathrm{ml})$ was included in RPMI 1640 medium. Cells were cultured at $37^{\circ} \mathrm{C}$ and $5 \%$ $\mathrm{CO}_{2}$ in the incubator. The medium was changed every 1 - 2 days.

There were a total of 14 experimental groups which were divided into control and experimental groups. The 14 experimental groups were as follows:

A1: DAC $20 \mu \mathrm{mol} / \mathrm{L}$; A2: DAC $40 \mu \mathrm{mol} / \mathrm{L} ; \mathrm{A} 3: \mathrm{DAC} 80 \mu \mathrm{mol} / \mathrm{L}$; 
B1: $\mathrm{AS}_{2} \mathrm{O}_{3} 1 \mu \mathrm{mol} / \mathrm{L} ; \mathrm{B} 2: \mathrm{AS}_{2} \mathrm{O}_{3} 2.5 \mu \mathrm{mol} / \mathrm{L} ; \mathrm{B} 3: \mathrm{AS}_{2} \mathrm{O}_{3} 5 \mu \mathrm{mol} / \mathrm{L}$;

$\mathrm{C} 1: \mathrm{A} 2+\mathrm{B} 2 ; \mathrm{C} 2: \mathrm{A} 3+\mathrm{B} 2$;

C3: A2 + B3; C4: A3 + B3;

D1: A3 (pretreatment) + B1; D2: A3 (pretreatment) + B2; D3: A3 (pretreatment) + B3;

E: control group.

\subsection{The Effect of DAC and $\mathrm{AS}_{2} \mathrm{O}_{3}$ of HL-60 on Cell Proliferation by CCK8}

HL-60 cells of logarithmic growth phase were adjusted at the concentration of $1 \times 10^{5} / \mathrm{ml}$ and they were inoculated in 96-well plates with volume of $100 \mu \mathrm{l}$ in each well. Various concentrations of the DAC or $\mathrm{AS}_{2} \mathrm{O}_{3}$ was added to each well with a final volume of $200 \mu \mathrm{l}$, and set up a blank control wells, each concentration was set with five wells. After incubated for $24 \mathrm{~h}, 48 \mathrm{~h}, 72 \mathrm{~h}$ with $5 \% \mathrm{CO}_{2}$ at $37^{\circ} \mathrm{C}$ in incubator, a total $20 \mu \mathrm{lCC} 8$ was added into each well dark and cultured in an incubator for $2 \mathrm{~h}$. The microplate reader was used to measure the absorbance value in each well at a wavelength of $450 \mathrm{~nm}$, and each mean value of triplicate wells was taken. OD values could reflect the number of survival cell, proliferation curve was drawn, and the inhibition of cell proliferation was calculated. The experiment was repeated for three times. The calculation formula was as follow:

Inhibition of cell proliferation rate $(\%)=(\mathrm{OD}$ control group - OD experimental group $) /(\mathrm{OD}$ control group OD zero set group) $\times 100 \%$

\subsection{Annexin V/PI Staining Detected the Apoptosis of HL-60 Cell}

HL-60 cells of logarithmic growth phase were adjusted at the concentration of $1 \times 10^{6} / \mathrm{ml}$, and they were inoculated in 6-well plates with volume of $1 \mathrm{ml}$ in each well. Different concentrations of the DAC or $\mathrm{AS}_{2} \mathrm{O}_{3}$ were added into each well with a final volume of $2 \mathrm{ml}$. After incubated for $24 \mathrm{~h}, 48 \mathrm{~h}, 72 \mathrm{~h}$ at $37^{\circ} \mathrm{C}$ in $5 \% \mathrm{CO}_{2}$ incubator, cells were strained by Annexin V/PI.

\subsection{DAPK Gene Amplification Using Real-Time PCR}

Total RNA was extracted and the reverse transcription reaction was carried out to obtain cDNA. The RT-PCR was performed in a total volume of $20 \mu \mathrm{l}$ containing $2 \mu \mathrm{l}$ cDNA, $10 \mu \mathrm{l} 2 \times$ All-in-One qPCR Mix, $1 \mu \mathrm{l}$ forward primer, $1 \mu \mathrm{l}$ reverse primer, $2 \mu \mathrm{l}$ st strand cDNA and $4 \mu \mathrm{l}$ deionized water. The RT-PCR conditions were as follows: 40 cycles at $94^{\circ} \mathrm{C}$ for $5 \mathrm{~min}, 94^{\circ} \mathrm{C}$ for $30 \mathrm{~s}, 55^{\circ} \mathrm{C}$ for $30 \mathrm{~s}, 72^{\circ} \mathrm{C}$ for $1 \mathrm{~min}$. The relative expression levels were detected by fluorescence ration PCR instrument and calculated using the $2^{-\Delta \Delta C \mathrm{Ct}}$ comparative CT method.

\subsection{Statistical Analysis}

SPSS 13.0 software was used for statistical analysis. All the data were expressed by the mean value of three independent experiments and the experimental results were showed as mean \pm standard deviation $(\bar{X} \pm S)$; T-test was used between two groups, analysis of variance was used to compare multiple groups, $P<0.05$ was considered to be statistically significant difference.

\section{Results}

\subsection{CCK8 Methods Detecting the Effect of Cell Proliferation}

HL-60 cells were treated with different concentrations of DAC $(20 \mu \mathrm{mol} / \mathrm{L}, 40 \mu \mathrm{mol} / \mathrm{L}, 80 \mu \mathrm{mol} / \mathrm{L}), \mathrm{AS}_{2} \mathrm{O}_{3}(1$ $\mu \mathrm{mol} / \mathrm{L}, 2.5 \mu \mathrm{mol} / \mathrm{L}, 5 \mu \mathrm{mol} / \mathrm{L}$ ) monotherapy for $24 \mathrm{~h}, 48 \mathrm{~h}, 72 \mathrm{~h}$, along with the extension of the drug concentration and time, proliferation inhibition rate had gradually increased. For DAC, the cell proliferation inhibition rate of HL-60 cells had increased from (10.97 \pm 1.09$) \%$ to (61.95 \pm 1.24$) \%$ (Figure 1(a)), while cell proliferation inhibition rate of $\mathrm{AS}_{2} \mathrm{O}_{3}$ monotherapy had increased from (13.81 \pm 3.09$) \%$ to (84.18 \pm 2.94$) \%$ (Figure 1(b)). The difference between the treatment groups were statistically significant $(P=0.00)$. Monotherapy of DAC, $\mathrm{AS}_{2} \mathrm{O}_{3}$ could inhibit the proliferation of HL-60 cells, and it was time- and dose-dependent.

The cell proliferation inhibition rate had increased from $(43.22 \pm 4.78) \%$ to $(93.12 \pm 3.71) \%$ when DAC (40 $\mu \mathrm{mol} / \mathrm{L}, 80 \mu \mathrm{mol} / \mathrm{L})$ was combined used with $\mathrm{AS}_{2} \mathrm{O}_{3}(2.5 \mu \mathrm{mol} / \mathrm{L}, 5 \mu \mathrm{mol} / \mathrm{L})$. Compared with monotherapy group, the proliferation inhibition rate was significantly increased and had statistically significant difference ( $P$ 


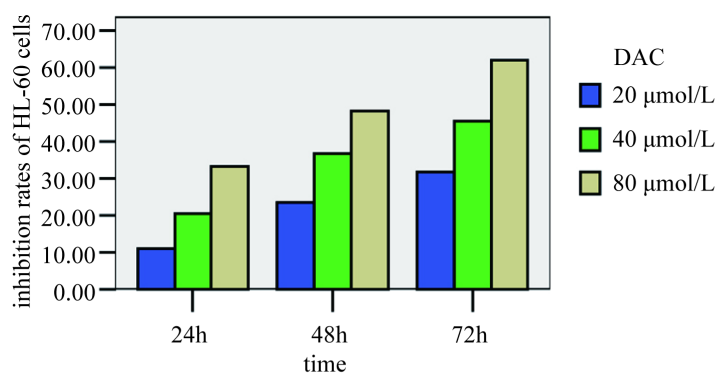

(a)

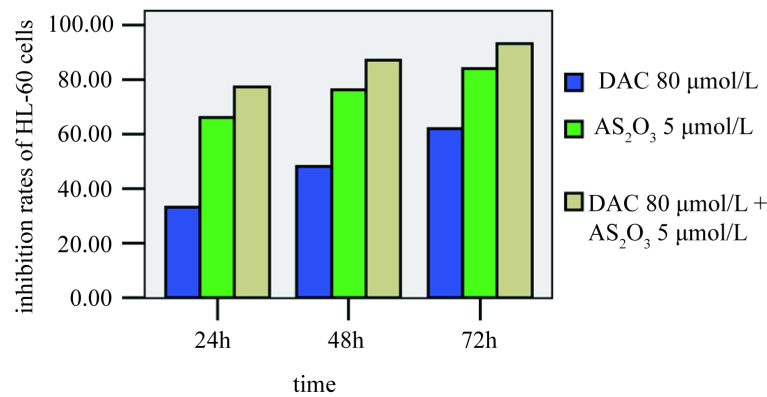

(c)

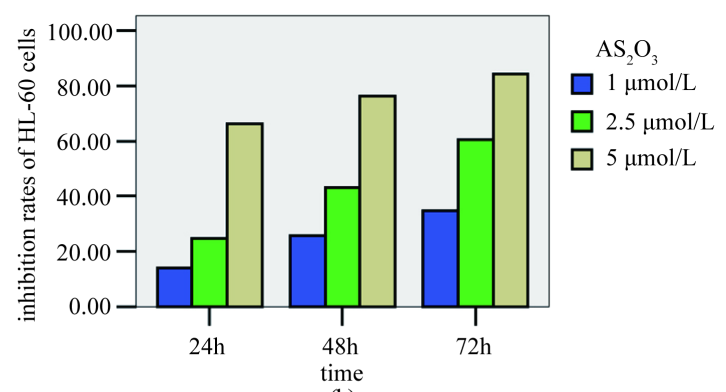

(b)

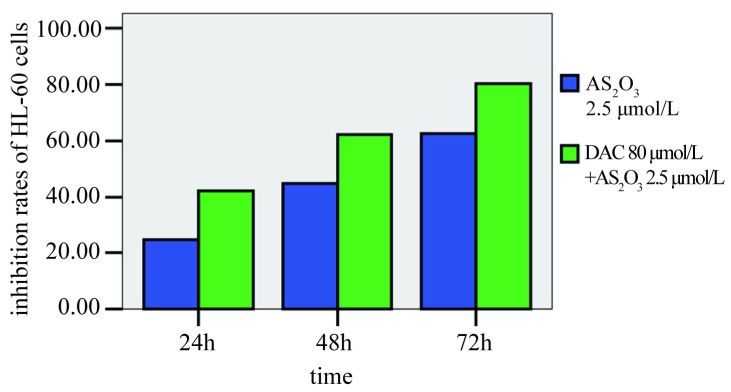

(d)

Figure 1. (a) The inhibition rates of HL-60 cells treated by different concentrations of DAC $(20 \mu \mathrm{mol} / \mathrm{L}, 40 \mu \mathrm{mol} / \mathrm{L}, 80$ $\mu \mathrm{mol} / \mathrm{L}$ ) for $24 \mathrm{~h}, 48 \mathrm{~h}, 72 \mathrm{~h}$; (b) The inhibition rates of HL-60 cells treated by different concentrations of $\mathrm{AS}_{2} \mathrm{O}_{3}(1 \mu \mathrm{mol} / \mathrm{L}$, $2.5 \mu \mathrm{mol} / \mathrm{L}, 5 \mu \mathrm{mol} / \mathrm{L})$ for $24 \mathrm{~h}, 48 \mathrm{~h}, 72 \mathrm{~h}$; (c) The inhibition rates of HL-60 cells treated by DAC (80 $\mu \mathrm{mol} / \mathrm{L}) \mathrm{combined}$ with $\mathrm{AS}_{2} \mathrm{O}_{3}(5 \mu \mathrm{mol} / \mathrm{L})$ for $24 \mathrm{~h}, 48 \mathrm{~h}, 72 \mathrm{~h}$; (d) After DAC $(80 \mu \mathrm{mol} / \mathrm{L})$ pretreatment, the inhibition rates of HL-60 cells treated by $\mathrm{AS}_{2} \mathrm{O}_{3}(2.5 \mu \mathrm{mol} / \mathrm{L})$ for $24 \mathrm{~h}, 48 \mathrm{~h}, 72 \mathrm{~h}$.

$=0.00)$. DAC and $\mathrm{AS}_{2} \mathrm{O}_{3}$ had a synergistic effect on HL-60 cell proliferation (Figure 1(c)). DAC $(80 \mu \mathrm{mol} / \mathrm{L})$ was firstly used for pretreatment, then, different concentrations of $\mathrm{AS}_{2} \mathrm{O}_{3}(1 \mu \mathrm{mol} / \mathrm{L}, 2.5 \mu \mathrm{mol} / \mathrm{L}, 5 \mu \mathrm{mol} / \mathrm{L})$ were used for $24 \mathrm{~h}, 48 \mathrm{~h}, 72 \mathrm{~h}$. It was found that cell proliferation inhibition rate had increase from $(31.8 \pm$ $1.32) \%$ to $(91.44 \pm 0.78) \%$ and compared with $\mathrm{AS}_{2} \mathrm{O}_{3}$ mono-therapy group, it could significantly enhance inhibiting cell proliferation (Figure 1(d)).

\subsection{The Effect of DAC and $\mathrm{AS}_{2} \mathrm{O}_{3}$ on Apoptosis of HL-60 Cell}

After HL-60 cells were treated with different concentrations of DAC $(20 \mu \mathrm{mol} / \mathrm{L}, 40 \mu \mathrm{mol} / \mathrm{L}, 80 \mu \mathrm{mol} / \mathrm{L})$, $\mathrm{AS}_{2} \mathrm{O}_{3}(1 \mu \mathrm{mol} / \mathrm{L}, 2.5 \mu \mathrm{mol} / \mathrm{L}, 5 \mu \mathrm{mol} / \mathrm{L})$ monotherapy for $24 \mathrm{~h}, 48 \mathrm{~h}, 72 \mathrm{~h}$, the apoptosis rate was gradually increased. For DAC, the apoptosis rate of HL-60 cells had increased from $(8.0 \pm 1.05) \%$ to (36.6 \pm 1.35$) \%$, and HL-60 cell apoptosis rate of $\mathrm{AS}_{2} \mathrm{O}_{3}$ monotherapy had increased from $(10.2 \pm 1.35) \%$ to $(45.3 \pm 2.35) \%$. The difference between the treatment groups were statistically significant $(P=0.00)$. Monotherapy of DAC, $\mathrm{AS}_{2} \mathrm{O}_{3}$ could induce apoptosis of HL-60 cells, and it was time- and dose-dependent (Figure 2).

The cell apoptosis rate had increased from $(19.6 \pm 0.56) \%$ to $(62.1 \pm 0.71) \%$ when DAC $(40 \mu \mathrm{mol} / \mathrm{L}, 80$ $\mu \mathrm{mol} / \mathrm{L})$ was combined used with $\mathrm{AS}_{2} \mathrm{O}_{3}(2.5 \mu \mathrm{mol} / \mathrm{L}, 5 \mu \mathrm{mol} / \mathrm{L})$. Compared with monotherapy group, apoptosis rate was significantly increased and had statistically significant difference $(P=0.00)$. DAC and $\mathrm{AS}_{2} \mathrm{O}_{3}$ had an synergistic effect on HL-60 apoptosis rate. DAC $(80 \mu \mathrm{mol} / \mathrm{L})$ was firstly used for pretreatment, then, different concentrations of $\mathrm{AS}_{2} \mathrm{O}_{3}(1 \mu \mathrm{mol} / \mathrm{L}, 2.5 \mu \mathrm{mol} / \mathrm{L}, 5 \mu \mathrm{mol} / \mathrm{L})$ were used for $24 \mathrm{~h}, 48 \mathrm{~h}, 72 \mathrm{~h}$. It was found that apoptosis rate had increase form $(18.8 \pm 1.32) \%$ to $(71.4 \pm 0.79) \%$ and compared with $\mathrm{AS}_{2} \mathrm{O}_{3}$ monotherapy group, it could significantly enhance inducing cell apoptosis (Figure 2).

\subsection{The DAPK mRNA Expression Level of HL-60 Cells after Treated with DAC and $\mathrm{AS}_{2} \mathrm{O}_{3}$}

After HL-60 cells were treated with different concentrations of DAC $(20 \mu \mathrm{mol} / \mathrm{L}, 40 \mu \mathrm{mol} / \mathrm{L}, 80 \mu \mathrm{mol} / \mathrm{L})$, $\mathrm{AS}_{2} \mathrm{O}_{3}(1 \mu \mathrm{mol} / \mathrm{L}, 2.5 \mu \mathrm{mol} / \mathrm{L}, 5 \mu \mathrm{mol} / \mathrm{L})$ monotherapy for $72 \mathrm{~h}$, mRNA expression of DAPK was gradually increased. For DAC, the mRNA expression of DAPK had increased from (1.5 \pm 0.34$)$ to (3.2 \pm 0.56$)$ (Table 1$)$, 

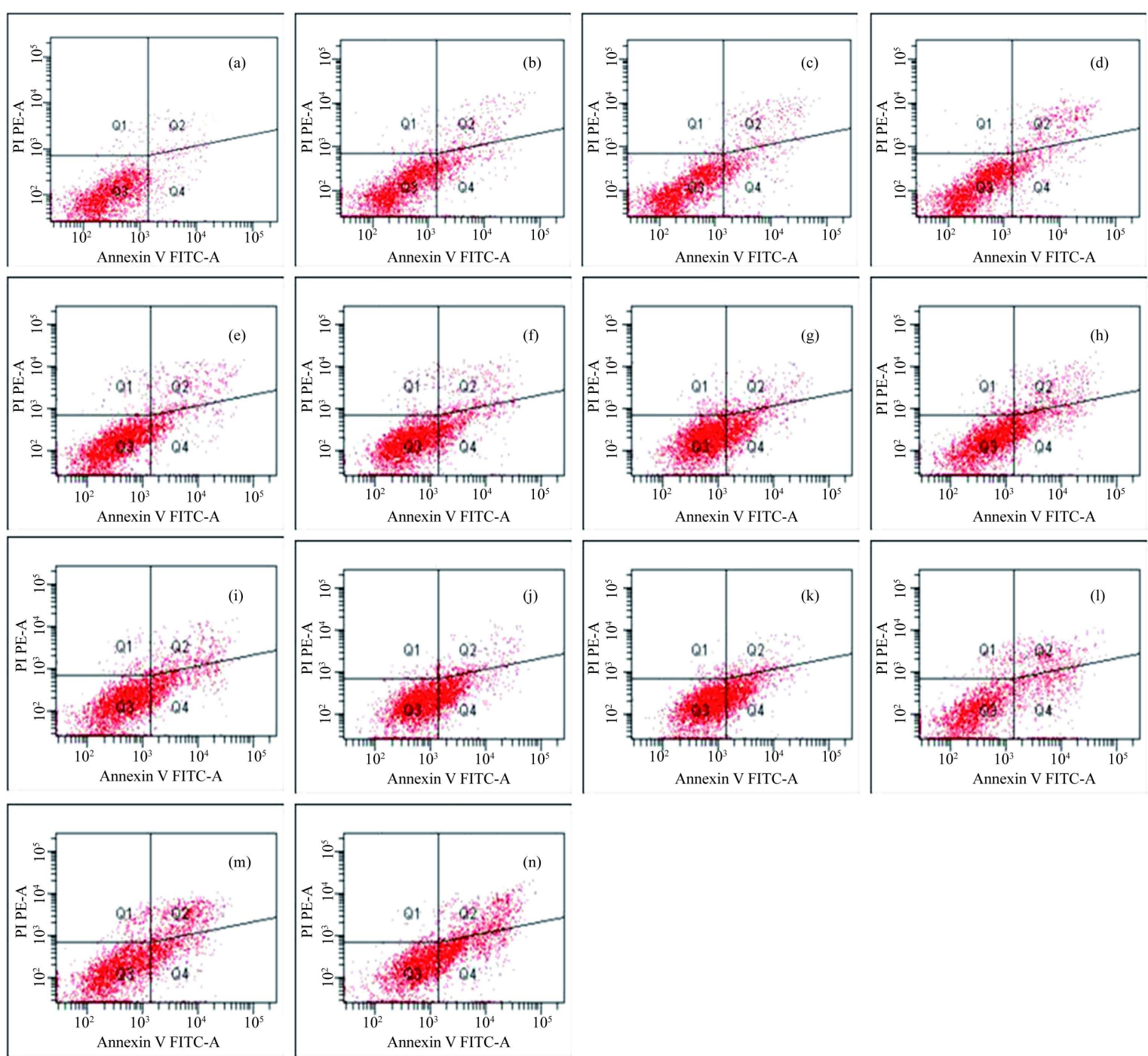

Figure 2. Apoptosis rates of HL-60 cells treated by different concentrations of DAC and $\mathrm{AS}_{2} \mathrm{O}_{3}$ for $48 \mathrm{~h}$, detected by flow cytometry ((a) control; (b): DAC $20 \mu \mathrm{mol} / \mathrm{L}$; (c): DAC $40 \mu \mathrm{mol} / \mathrm{L}$; (d): DAC $80 \mu \mathrm{mol} / \mathrm{L}$; (e): $\mathrm{AS}_{2} \mathrm{O}_{3} 1 \mu \mathrm{mol} / \mathrm{L}$; (f): $\mathrm{AS}_{2} \mathrm{O}_{3}$ $2.5 \mu \mathrm{mol} / \mathrm{L}$; (g): $\mathrm{AS}_{2} \mathrm{O}_{3} 5 \mu \mathrm{mol} / \mathrm{L}$; (h): DAC $40 \mu \mathrm{mol} / \mathrm{L}+\mathrm{AS}_{2} \mathrm{O}_{3} 2.5 \mu \mathrm{mol} / \mathrm{L}$; (i): DAC $80 \mu \mathrm{mol} / \mathrm{L}+\mathrm{AS}_{2} \mathrm{O}_{3} 2.5 \mu \mathrm{mol} / \mathrm{L} ;(\mathrm{j})$ : $\mathrm{DAC} 40 \mu \mathrm{mol} / \mathrm{L}+\mathrm{AS}_{2} \mathrm{O}_{3} 5 \mu \mathrm{mol} / \mathrm{L}$; (k): DAC $80 \mu \mathrm{mol} / \mathrm{L}+\mathrm{AS}_{2} \mathrm{O}_{3} 5 \mu \mathrm{mol} / \mathrm{L}$; (l): DAC $80 \mu \mathrm{mol} / \mathrm{L}$ (pretreatment) $+\mathrm{AS}_{2} \mathrm{O}_{3} 1$ $\mu \mathrm{mol} / \mathrm{L}$; (m): DAC $80 \mu \mathrm{mol} / \mathrm{L}$ (pretreatment) $+\mathrm{AS}_{2} \mathrm{O}_{3} 2.5 \mu \mathrm{mol} / \mathrm{L}$; (n): DAC $80 \mu \mathrm{mol} / \mathrm{L}$ (pretreatment) $+\mathrm{AS}_{2} \mathrm{O}_{3} 5 \mu \mathrm{mol} / \mathrm{L}$ ).

Table 1. The expression level of DAPK mRNA in HL-60 cells after treated by different concentrations of DAC for $72 \mathrm{~h}$.

\begin{tabular}{cc}
\hline DAC $(\mu \mathrm{mol} / \mathrm{L})$ & Expression level $(\bar{X} \pm \mathrm{S})$ \\
\hline 0 & $0.3 \pm 0.32$ \\
20 & $1.5 \pm 0.34^{*}$ \\
40 & $2.6 \pm 0.48^{*}$ \\
80 & $3.2 \pm 0.56^{*}$ \\
\hline
\end{tabular}

$* \mathrm{P}=0.00$, compared among each group.

and mRNA expression of DAPK of $\mathrm{AS}_{2} \mathrm{O}_{3}$ monotherapy had increased from (1.2 \pm 0.50$)$ to (3.0 \pm 0.17$)$ (Table 2).

The mRNA expression of DAPK had increased from (3.6 \pm 0.47$)$ to $(5.2 \pm 0.25)$ when DAC $(40 \mu \mathrm{mol} / \mathrm{L}, 80$ 
$\mu \mathrm{mol} / \mathrm{L})$ was combined used with $\mathrm{AS}_{2} \mathrm{O}_{3}(2.5 \mu \mathrm{mol} / \mathrm{L}, 5 \mu \mathrm{mol} / \mathrm{L})$ (Table 3). Compared with monotherapy group, mRNA expression of DAPK was significantly increased and had statistically significant difference $(P=0.00)$. DAC and $\mathrm{AS}_{2} \mathrm{O}_{3}$ had a synergistic effect on mRNA expression of DAPK. DAC $(80 \mu \mathrm{mol} / \mathrm{L})$ was firstly used for pretreatment, then, different concentrations of $\mathrm{AS}_{2} \mathrm{O}_{3}(1 \mu \mathrm{mol} / \mathrm{L}, 2.5 \mu \mathrm{mol} / \mathrm{L}, 5 \mu \mathrm{mol} / \mathrm{L})$ were used for $72 \mathrm{~h}$. It was found that mRNA expression of DAPK had increase form $(2.0 \pm 0.35)$ to $(4.5 \pm 0.18)$ and compared with $\mathrm{AS}_{2} \mathrm{O}_{3}$ monotherapy group, it could significantly enhance mRNA expression level of DAPK (Table 4).

\section{Discussion}

Death-associated protein kinase (DAPK) is a tumor suppressor gene, apoptosis system is activated at the beginning of apoptosis, and the expression levels increase with increased apoptosis. Study has shown that apoptosis process is closely related to the development and tumor metastasis or DAPK gene expression levels. DAPK can activate the classical p53-caspase apoptosis pathway or caspase-independent apoptosis in multiple apoptotic pathways, it is considered likely to be multiple signal DAPK confluence of apoptosis [24] [25]. It has been confirmed that the former after DAC treatment, with the resumption of DAPK gene expression, apoptosis rate is also increased [26]. The methylation of DAPK gene promoter is an important indicator for leukemia prognosis [26]-[28].

Table 2. The expression level of DAPK mRNA in HL-60 cells after treated by different concentrations of $\mathrm{AS}_{2} \mathrm{O}_{3}$ for $72 \mathrm{~h}$.

\begin{tabular}{|c|c|}
\hline $\mathrm{AS}_{2} \mathrm{O}_{3}(\mu \mathrm{mol} / \mathrm{L})$ & Expression level $(\bar{X} \pm \mathrm{S})$ \\
\hline 0 & $0.3 \pm 0.21$ \\
\hline 1 & $1.2 \pm 0.50^{*}$ \\
\hline 2.5 & $2.4 \pm 0.33^{*}$ \\
\hline 5 & $3.0 \pm 0.17^{*}$ \\
\hline
\end{tabular}

$* \mathrm{P}=0.00$, compared among each group.

Table 3. The expression level of DAPK mRNA in HL-60 cells after treated by different concentrations of DAC combined with $\mathrm{AS}_{2} \mathrm{O}_{3}$ for $72 \mathrm{~h}$.

\begin{tabular}{cc}
\hline group & Expression level $\left(\begin{array}{ll}\bar{X} & \pm S\end{array}\right)$ \\
\hline 0 & $0.3 \pm 0.20$ \\
C1 & $3.6 \pm 0.47^{*}$ \\
C2 & $4.8 \pm 0.21^{*}$ \\
C3 & $4.5 \pm 0.11^{*}$ \\
C4 & $5.2 \pm 0.25^{*}$
\end{tabular}

$* \mathrm{P}=0.00$, compared with the single drug group $\left(\mathrm{C} 1\right.$ : DAC $40 \mu \mathrm{mol} / \mathrm{L}+\mathrm{AS}_{2} \mathrm{O}_{3} 2.5 \mu \mathrm{mol} / \mathrm{L} ; \mathrm{C} 2$ : DAC 80 $\mu \mathrm{mol} / \mathrm{L}+\mathrm{AS}_{2} \mathrm{O}_{3} 2.5 \mu \mathrm{mol} / \mathrm{L} ; \mathrm{C} 3: \mathrm{DAC} 40 \mu \mathrm{mol} / \mathrm{L}+\mathrm{AS}_{2} \mathrm{O}_{3} 5 \mu \mathrm{mol} / \mathrm{L} ; \mathrm{C} 4: \mathrm{DAC} 80 \mu \mathrm{mol} / \mathrm{L}+\mathrm{AS}_{2} \mathrm{O}_{3} 5$ $\mu \mathrm{mol} / \mathrm{L})$.

Table 4. After DAC $(80 \mu \mathrm{mol} / \mathrm{L})$ pretreatment, the expression level of DAPK mRNA in HL60 cells after treated by different concentrations of $\mathrm{AS}_{2} \mathrm{O}_{3}$ for $72 \mathrm{~h}$.

\begin{tabular}{cc}
\hline DAC (pretreatmen) $+\mathrm{AS}_{2} \mathrm{O}_{3}(\mu \mathrm{mol} / \mathrm{L})$ & Expression level $(\bar{X} \pm \mathrm{S})$ \\
\hline 0 & $0.3 \pm 0.22$ \\
1 & $2.0 \pm 0.35^{*}$ \\
2.5 & $3.2 \pm 0.21^{*}$ \\
5 & $4.5 \pm 0.18^{*}$ \\
\hline
\end{tabular}

$* \mathrm{P}=0.00$, compared with the single drug group of $\mathrm{AS}_{2} \mathrm{O}_{3}$ and each treatment group. 
Decitabine (DAC) is a cytosine analogue, as a new generation of specific inhibitor of DNA methylation, it can play DNA demethylation, and activate silent tumor suppressor genes. The previous studies have shown that after treated with DAC for 72 hours, the proportion of HL-60 cells in G0/G1 phase had increased, and the proportion of HL-60 cells in S phase had reduced. This indicated that the DAC can inhibit the cell proliferation. Soncini M et al. [29] had found that DAC can induce NB4 cell apoptosis, and its mechanism may be related to activation of the extrinsic apoptosis pathway. The mechanisms that $\mathrm{AS}_{2} \mathrm{O}_{3}$ induced apoptosis include: accelerated the expression level of p53 gene, down-regulated the expression level of bcl-2 gene, activated Caspase pathway and reducted membrane potential of mitochondrial [30] [31]. Some researchers have shown that $\mathrm{AS}_{2} \mathrm{O}_{3}$ could significantly inhibit HL-60 cell proliferation and induce apoptosis. Its mechanism may be related to the inhibition of extracellular signal-regulated kinase (ERK) signal transduction pathway.

In this study, a different concentration of DAC $(20 \mu \mathrm{mol} / \mathrm{L}, 40 \mu \mathrm{mol} / \mathrm{L}, 80 \mu \mathrm{mol} / \mathrm{L})$ and $\mathrm{AS}_{2} \mathrm{O}_{3}(1 \mu \mathrm{mol} / \mathrm{L}, 2.5$ $\mu \mathrm{mol} / \mathrm{L}, 5 \mu \mathrm{mol} / \mathrm{L}$ ) treatment was selected for HL-60 cells to compare the DAC and $\mathrm{AS}_{2} \mathrm{O}_{3}$ monotherapy and combination treatment. CCK8 method was used to detect the cell proliferation and the results showed that effective inhibition of cell proliferation was time- and dose-dependent. After the two-drug combination, the inhibition rate was significantly enhanced, which indicated a synergistic effect of the two drugs. Beside this, the cell apoptosis and mRNA expression level detection also should be the obvious synergistic effect between DAC and $\mathrm{AS}_{2} \mathrm{O}_{3}$. This study found a relative low DAPK gene expression in HL-60 cells before drug intervention. DAPK gene significantly increased after demethylation and cell proliferation was inhibited, the apoptosis rate increased significantly, thus the reactivation of DAPK gene may be one of the mechanisms DAC induced apoptosis in HL-60 cells.

\section{Conclusion}

In summary, DAC or $\mathrm{AS}_{2} \mathrm{O}_{3}$ single drug could inhibit HL-60 cell proliferation and induce cell apoptosis, and it had a time- and dose-dependent manner. At the same time, we found that the inhibition of proliferation and the apoptosis effect of DAC combined with $\mathrm{AS}_{2} \mathrm{O}_{3}$ group were more obvious than single drug group, suggesting that the two drugs have a synergistic effect. The DAC pretreatment could enhance the sensibility of $\mathrm{AS}_{2} \mathrm{O}_{3}$ and increase the expression level of DAPK gene. Our study may provide a significant theoretical basis for the study in HL-60 cell proliferation and apoptosis.

\section{References}

[1] Roman-Gomez, J., Jimenez-Velasco, A., Castillejo, J.A., Agirre, X., et al. (2004) Promoter Hypermethylation of Cancer-Related Genes: A Strong Independent Prognostic Factor in Acute Lymphoblastic Leukemia. Blood, 104, 24922498. http://dx.doi.org/10.1182/blood-2004-03-0954

[2] Rossi, D., Capello, D., Gloghini, A., Franceschetti, S., et al. (2004) Aberrant Promoter Methylation of Multiple Genes throughout the Clinico-Pathologic Spectrum of B-Cell Neoplasia. Haematologica, 89, 154-64.

[3] Jabbour, E., Issa, J.P., Garcia-Manero, G. and Kantarjian, H. (2008) Evolution of Decitabine Development: Accomplishments, Ongoing Investigations, and Future Strategies. Cancer, 112, 2341-2351. http://dx.doi.org/10.1002/cncr.23463

[4] Schmelz, K., Wagner, M., Dorken, B. and Tamm, I. (2005) 5-Aza-2'-deoxycytidine Induces p21WAF Expression by Demethylation of p73 Leading to p53-Independent Apoptosis in Myeloid Leukemia. International Journal of Cancer, 114, 683-695. http://dx.doi.org/10.1002/ijc.20797

[5] Wijermans, P., Lubbert, M., Verhoef, G., Bosly, A., et al. (2000) Low-dose 5-Aza-2'-deoxycytidine, a DNA Hypomethylating Agent, for the Treatment of High-Risk Myelodysplastic Syndrome: A Multicenter Phase II Study in Elderly Patients. Journal of Clinical Oncology, 18, 956-962.

[6] Kantarjian, H.M., O’Brien, S., Cortes, J., Giles, F.J., et al. (2003) Results of Decitabine (5-Aza-2'deoxycytidine) Therapy in 130 Patients with Chronic Myelogenous Leukemia. Cancer, 98, 522-528. http://dx.doi.org/10.1002/cncr.11543

[7] Khan, H., Vale, C., Bhagat, T. and Verma, A. (2013) Role of DNA Methylation in the Pathogenesis and Treatment of Myelodysplastic Syndromes. Seminars in Hematology, 50, 16-37. http://dx.doi.org/10.1053/j.seminhematol.2013.01.001

[8] Blum, W., Klisovic, R.B., Hackanson, B., Liu, Z., et al. (2007) Phase I Study of Decitabine Alone or in Combination with Valproic Acid in Acute Myeloid Leukemia. Journal of Clinical Oncology, 25, 3884-3891.

http://dx.doi.org/10.1200/JCO.2006.09.4169 
[9] Cashen, A.F., Schiller, G.J., O’Donnell, M.R. and DiPersio, J.F. (2010) Multicenter, Phase II Study of Decitabine for the First-Line Treatment of Older Patients with Acute Myeloid Leukemia. Journal of Clinical Oncology, 28, 556-561. http://dx.doi.org/10.1200/JCO.2009.23.9178

[10] Plimack, E.R., Kantarjian, H.M. and Issa, J.P. (2007) Decitabine and Its Role in the Treatment of Hematopoietic Malignancies. Leukemia \& Lymphoma, 48, 1472-1481. http://dx.doi.org/10.1080/10428190701471981

[11] Malik, P. and Cashen, A.F. (2014) Decitabine in the Treatment of Acute Myeloid Leukemia in Elderly Patients. Cancer Management and Research, 6, 53-61.

[12] Ho, S.Y., Wu Jr., W., Chiu, H.W., et al. (2011) Arsenic Trioxide and Radiation Enhance Apoptotic Effects in HL-60 Cells through Increased ROS Generation and Regulation of JNK and p38 MAPK Signaling Pathways. Chemico-Biological Interactions, 193, 162-171. http://dx.doi.org/10.1016/j.cbi.2011.06.007

[13] Zhao, D., Jiang, Y., Dong, X., et al. (2011) Arsenic Trioxide Reduces Drug Resistance to Adriamycin in Leukemic K562/A02 Cells via Multiple Mechanisms. Biomedicine \& Pharmacotherapy, 65, 354-358. http://dx.doi.org/10.1016/j.biopha.2011.04.016

[14] Yang, L., Luo, J.M., Li, Y., et al. (2009) $\mathrm{As}_{2} \mathrm{O}_{3}$ Induces Demethylation and Upregulates Transeription of SHP-1 Gene in Human Lymphoma Cell Line T2 Cells. Chinese Journal of Oncology, 31, 423-427.

[15] Gandesiri, M., Chakilam, S., Ivanovska, J., Benderska, N., et al. (2012) DAPK Plays an Important Role in Panobinostat-Induced Autophagy and Commits Cells to Apoptosis under Autophagy Deficient Conditions. Apoptosis, 17, 13001315. http://dx.doi.org/10.1007/s10495-012-0757-7

[16] Gade, P., Ramachandran, G., Maachani, U.B., Rizzo, M.A., et al. (2012) An IFN-Gamma-Stimulated ATF6-C/EBPBeta-Signaling Pathway Critical for the Expression of Death Associated Protein Kinase 1 and Induction of Autophagy. Proceedings of the National Academy of Sciences of the United States of America, 109, 10316-10321. http://dx.doi.org/10.1073/pnas.1119273109

[17] Schneider-Stock, R., Kuester, D., Ullrich, O., Mittag, F., et al. (2006) Close Localization of DAP-Kinase Positive Tumour-Associated Macrophages and Apoptotic Colorectal Cancer Cells. Journal of Pathology, 209, 95-105. http://dx.doi.org/10.1002/path.1951

[18] Luo, X.J., Li, L.L., Deng, Q.P., Yu, X.F., et al. (2011) Grifolin, a Potent Antitumour Natural Product Upregulates Death-Associated Protein Kinase 1 DAPK1 via p53 in Nasopharyngeal Carcinoma Cells. European Journal of Cancer, 47, 316-325. http://dx.doi.org/10.1016/j.ejca.2010.09.021

[19] Inbal, B., Bialik, S., Sabanay, I., Shani, G., et al. (2002) DAP Kinase and DRP-1 Mediate Membrane Blebbing and the Formation of Autophagic Vesicles during Programmed Cell Death. Journal of Cell Biology, 157, 455-468. http://dx.doi.org/10.1083/jcb.200109094

[20] Eisenberg-Lerner, A. and Kimchi, A. (2007) DAP Kinase Regulates JNK Signaling by Binding and Activating Protein Kinase D under Oxidative Stress. Cell Death \& Differentiation, 14, 1908-1915. http://dx.doi.org/10.1038/sj.cdd.4402212

[21] Tahara, T., Shibata, T., Nakamura, M., Okubo, M., et al. (2011) Polymorphisms of DNA Repair and Xenobiotic Genes Predispose to CpG Island Methylation in Non-Neoplastic Gastric Mucosa. Helicobacter, 16, 99-106. http://dx.doi.org/10.1111/j.1523-5378.2011.00821.x

[22] Su, Y., Xu, H., Xu, Y., Yu, J., et al. (2012) Azacytidine Inhibits the Proliferation of Human Promyelocytic Leukemia Cells (HL60) by Demethylation of MGMT, DAPK and p16 Genes. Hematology, 17, 41-46. http://dx.doi.org/10.1179/102453312X13221316477624

[23] Niu, Y.M., Wang, P.P., Wang, Y., Wang, Y.Z., et al. (2014) Expression of Death-Associated Protein Kinase Gene and Methylation Status of Promoter Region in Acute Leukemia. Journal of Experimental Hematology, 22, 30-34.

[24] Liu, X.F., Tang, K., Yu, S.P., Wang, Z.Q., et al. (2012) Correlation between Promoter Methylation of p14(ARF), TMS1/ASC, and DAPK, and p53 Mutation with Prognosis in Cholangiocarcinoma. World Journal of Surgical Oncology, 10, 5. http://dx.doi.org/10.1186/1477-7819-10-5

[25] Liu, Y., Gao, W., Siegfried, J.M., Weissfeld, J.L., et al. (2007) Promoter Methylation of RASSF1A and DAPK and Mutations of K-ras, p53, and EGFR in Lung Tumors from Smokers and Never-Smokers. BMC Cancer, 7, 74. http://dx.doi.org/10.1186/1471-2407-7-74

[26] Wu, J., Hu, C.P., Gu, Q.H., Li, Y.P., et al. (2010) Trichostatin A Sensitizes Cisplatin-Resistant A549 Cells to Apoptosis by Up-Regulating Death-Associated Protein Kinase. Acta Pharmacologica Sinica, 31, 93-101. http://dx.doi.org/10.1038/aps.2009.183

[27] Nair, S., Hagberg, H., Krishnamurthy, R., Thornton, C., et al. (2013) Death Associated Protein Kinases: Molecular Structure and Brain Injury. International Journal of Molecular Sciences, 14, 13858-13872. http://dx.doi.org/10.3390/ijms140713858

[28] Widau, R.C., Jin, Y., Dixon, S.A., Wadzinski, B.E., et al. (2010) Protein Phosphatase 2A (PP2A) Holoenzymes Regu- 
late Death-Associated Protein Kinase (DAPK) in Ceramide-Induced Anoikis. Journal of Biological Chemistry, 285, 13827-13838. http://dx.doi.org/10.1074/jbc.M109.085076

[29] Soncini, M., Santoro, F., Gutierrez, A., Frige, G., et al. (2013) The DNA Demethylating Agent Decitabine Activates the TRAIL Pathway and Induces Apoptosis in Acute Myeloid Leukemia. Biochimica et Biophysica Acta, 1832, 114120. http://dx.doi.org/10.1016/j.bbadis.2012.10.001

[30] Ge, F., Lu, X.P., Zeng, H.L., He, Q.Y., et al. (2009) Proteomic and Functional Analyses Reveal a Dual Molecular Mechanism Underlying Arsenic-Induced Apoptosis in Human Multiple Myeloma Cells. Journal of Proteome Research, 8, 3006-3019. http://dx.doi.org/10.1021/pr9001004

[31] Morales, A.A., Gutman, D., Cejas, P.J., Lee, K.P., et al. (2009) Reactive Oxygen Species Are Not Required for an Arsenic Trioxide-Induced Antioxidant Response or Apoptosis. Journal of Biological Chemistry, 284, 12886-12895.

http://dx.doi.org/10.1074/jbc.M806546200 